\title{
NPPC/NPR2 signaling is essential for oocyte meiotic arrest and cumulus oophorus formation during follicular development in the mouse ovary
}

\author{
Chiyo Kiyosu, Takehito Tsuji, Kaoru Yamada, Shimpei Kajita and Tetsuo Kunieda \\ Graduate School of Natural Science and Technology, Okayama University, Tsushima-naka, Okayama 700-8530, \\ Japan
}

Correspondence should be addressed to T Tsuji; Email: takehito@cc.okayama-u.ac.jp

\begin{abstract}
Natriuretic peptide type C (NPPC) and its high affinity receptor, natriuretic peptide receptor 2 (NPR2), have been assumed to be involved in female reproduction and have recently been shown to play an essential role in maintaining meiotic arrest of oocytes. However, the overall role of NPPC/NPR2 signaling in female reproduction and ovarian function is still less clear. Here we report the defects observed in oocytes and follicles of mice homozygous for $\mathrm{Nppc}^{\text {lbab }}$ or $\mathrm{Npr}^{\mathrm{cn}}$, mutant alleles of $\mathrm{Nppc}$ or Npr2 respectively to clarify the exact consequences of lack of NPPC/NPR2 signaling in female reproductive systems. We found that: i) $N p r 2^{c n} / N p r 2^{c n}$ female mice ovulated a comparable number of oocytes as normal mice but never produced a litter; ii) all ovulated oocytes of $N p r 2^{c n} / N p r 2^{c n}$ and $\mathrm{Nppc}^{\text {lbab }} / \mathrm{Nppc}^{\text {lbab }}$ mice exhibited abnormalities, such as fragmented or degenerated ooplasm and never developed to the two-cell stage after fertilization; iii) histological examination of the ovaries of $N p r 2^{c n} / N p r 2^{c n}$ and Nppc $c^{l b a b} / N p p c c^{l b a b}$ mice showed that oocytes in antral follicles prematurely resumed meiosis and that immediately before ovulation, oocytes showed disorganized chromosomes or fragmented ooplasm; and iv) ovulated oocytes and oocytes in the periovulatory follicles of the mutant mice were devoid of cumulus cells. These findings demonstrate that NPPC/NPR2 signaling is essential for oocyte meiotic arrest and cumulus oophorus formation, which affects female fertility through the production of oocytes with developmental capacity.
\end{abstract}

Reproduction (2012) 144 187-193

\section{Introduction}

Natriuretic peptide type C (NPPC) is a member of the natriuretic peptide family, which also includes natriuretic peptide type $A$ (NPPA) and natriuretic peptide type B (NPPB) in mammals (Potter et al. 2006). NPPC exerts its biological action as a local factor by binding to a high affinity receptor, natriuretic peptide receptor 2 (NPR2), followed by the production of intracellular cGMP via the guanylyl cyclase catalytic domains of NPR2 (Suga et al. 1992). NPPC has been shown to be associated with various physiological functions in mammals (Schulz 2005). In particular, its physiological role in regulating longitudinal bone growth has been revealed using genetically altered mice (Chusho et al. 2001, Tamura et al. 2004).

Expression of the Nppc and Npr2 is higher in the ovary and uterus than in other tissues (Stepan et al. 2000). These genes are also detected in granulosa cells and are modulated by the estrous cycle in rats (Jankowski et al. 1997). In addition, cGMP is involved in the regulation of oocyte meiotic arrest (Törnell et al. 1990) and ovarian follicle survival (McGee et al. 1997). These observations suggest that NPPC/NPR2 signaling may play an important role in female reproduction. Recently, Zhang et al. (2010) reported that NPPC and NPR2 play an essential role in maintaining meiotic arrest of oocytes and that a significant number of oocytes in Nppc or Npr2 mutant mice exhibit premature resumption at the late antral stage. However, the overall role of NPPC/NPR2 signaling in female reproduction, including follicle development, oocyte maturation, and ovulation, remains to be elucidated.

Achondroplasia $(\mathrm{CN})$ and long bone abnormality (LBAB) are spontaneous mutant mouse strains characterized by disproportionate dwarfism with short limbs and tails (Lane \& Dickie 1968, Jiao et al. 2007). Missense mutations have been identified as the causative genetic alterations in the Npr2 and $\mathrm{Nppc}$ genes of the $\mathrm{CN}$ and LBAB mice respectively (Tsuji \& Kunieda 2005, Jiao et al. 2007). These mutations, represented as $\mathrm{Npr}^{\mathrm{cn}}$ and $N p p c^{\text {Ibab }}$, have been confirmed to impair function of the NPPC/NPR2/cGMP system (Tsuji \& Kunieda 2005, Tsuji et al. 2008). In this study, we investigated detailed phenotypes in the oocytes and ovaries of $N p r 2^{\mathrm{cn}} / \mathrm{Npr} 2^{\mathrm{cn}}$

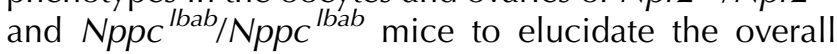
role of NPPC/NPR2 signaling in female reproduction. 
Table 1 Mating test of $\mathrm{Npr} 2^{c n} / \mathrm{Npr} 2^{c n}$ mice.

\begin{tabular}{lcc}
\hline $\begin{array}{l}\text { Genotype of } \\
\text { female mice }\end{array}$ & $\begin{array}{c}\text { Number of } \\
\text { successful mating }\end{array}$ & $\begin{array}{c}\text { Litter size } \\
\text { (mean } \pm \text { s.D. })\end{array}$ \\
\hline$+/ ?(n=6)$ & 6 & $6.6 \pm 2.7$ \\
$N p r 2^{c n} / N p r 2^{c n}(n=5)$ & 5 & 0 \\
\hline
\end{tabular}

\section{Results}

\section{Fertility of $\mathrm{Npr}^{\mathrm{cn}} \mathrm{Npr}^{\mathrm{cn}}$ female mice}

To confirm that the lack of NPPC/NPR2 signaling results in defective reproductive ability in mice, the fertility of $\mathrm{Npr} 2^{\mathrm{Cn}} / \mathrm{Npr}^{\mathrm{Cn}}$ and normal (+/?) female mice was examined by a mating test with normal male mice. Successful mating, as judged by the presence of a vaginal plug, was confirmed in five $\mathrm{Npr} 2^{\mathrm{cn}} / \mathrm{Npr} 2^{\mathrm{cn}}$ female mice and six normal female mice. In addition, we observed all stages of the estrus cycle, namely, proestrus, estrus, metestrus, and diestrus stages, in the $\mathrm{Npr} 2^{\mathrm{cn}} / \mathrm{Npr} 2^{\mathrm{cn}}$ mice based on the cytology of vaginal smears; however, the cycle of these stages was not as clear as in the normal $(+/$ ?) mice (data not shown). No signs of pregnancy or delivery of pups were observed in $N p r 2^{c n} / \mathrm{Npr}^{2 n}$ mice, whereas the normal mice gave birth to an average of 6.6 pups (Table 1). These results indicate that although female mice lacking NPPC/NPR2 signaling have estrus cycle and mating ability, they are infertile.

\section{Morphology of ovulated oocytes in $\mathrm{Npr}^{\mathrm{cn}} \mathrm{Npr}^{\mathrm{cn}}$ female mice}

We assessed the oocytes ovulated from $\mathrm{Npr} 2^{\mathrm{cn}} / \mathrm{Npr} 2^{\mathrm{cn}}$ mice to investigate the etiology of infertility. First, the number of ovulated oocytes was counted in both naturally ovulated and superovulated $\mathrm{Npr} 2^{\mathrm{cn}} / \mathrm{Npr} 2^{\mathrm{cn}}$ female mice at 10-12 weeks of age. As shown in Fig. 1, although the number of oocytes was significantly lesser in naturally ovulated $N p r 2^{c n} / N p r 2^{c n}$ mice than in normal $(+/$ ?) mice, ovulation of oocytes was confirmed in $\mathrm{Npr} 2^{\mathrm{cn}} / \mathrm{Npr} 2^{\mathrm{cn}}$ mice. Furthermore, no significant difference was found in the number of oocytes between the superovulated $N p r 2^{c n} / N p r 2^{c n}$ and normal $(+/$ ?) mice. These findings indicated that the follicular development and ovulation processes appear to be unaffected in $\mathrm{Npr} 2^{\mathrm{cn}} / \mathrm{Npr} 2^{\mathrm{cn}}$ mice and that the infertility of $N p r 2^{c n} / N p r 2^{c n}$ female mice is not caused by lack of ovulated oocytes.

However, no cumulus cells were observed around the ovulated oocytes of $\mathrm{Npr} 2^{c n} / \mathrm{Npr} 2^{c n}$ mice, whereas oocytes were ovulated as oocyte-cumulus cell complexes in normal mice, implying aberrant development of cumulus cells in the ovaries of $\mathrm{Npr} 2^{\mathrm{cn}} / \mathrm{Npr} 2^{\mathrm{cn}}$ mice (data not shown). Furthermore, under stereomicroscopic observation, a significant number of the ovulated oocytes of $\mathrm{Npr} 2^{\mathrm{cn}} / \mathrm{Npr} 2^{\mathrm{cn}}$ mice appeared to be fragmented. Immunocytochemical staining using anti- $\alpha$-tubulin antibody revealed that the ovulated oocytes of the normal mice were arrested at MII stage, as demonstrated by appropriate meiotic spindle structure and chromosome alignment and a clearly evident excreted polar body (Fig. 2A). In contrast, all oocytes collected from the superovulated $\mathrm{Npr} 2^{\mathrm{cn}} / \mathrm{Npr} 2^{\mathrm{cn}}$ mice showed condensed chromatin with or without fragmented cytoplasm, and no meiotic spindle or chromosome configurations were observed (Fig. 2B). At 1.5 days after coitus, the fertilized eggs collected from the normal female mice had reached the two-cell stage (Fig. 2C), whereas those collected from the $\mathrm{Npr} 2^{\mathrm{cn}} / \mathrm{Npr} 2^{\mathrm{cn}}$ mice exhibited morphologically abnormal with fragmented or degenerated cytoplasm (Fig. 2D). These results indicate that abnormal oocytes with no developmental capacity were ovulated in the

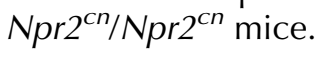

\section{Histology of ovaries of $\mathrm{Npr}^{\mathrm{cn}} / \mathrm{Npr}^{\mathrm{cn}}$ female mice}

The ovaries of $\mathrm{Npr} 2^{\mathrm{cn}} / \mathrm{Npr2^{cn }}$ mice were histologically examined to determine the nature of abnormalities occurring during oogenesis. In the ovaries of 12-weekold $\mathrm{Npr} 2^{\mathrm{cn}} / \mathrm{Npr} 2^{\mathrm{cn}}$ mice, primary, preantral, and antral stage follicles were observed, as in normal mice, but the gross appearance of the ovaries in these mice was smaller than those of normal mice. In normal mice, oocytes in the follicles at these stages are arrested at prophase of the first meiotic division until the induction of maturation by the preovulatory LH surge, which is characterized by the presence of a visible germinal vesicle (GV) as shown in Fig. $3 \mathrm{~A}$. However, in antral follicles of the $\mathrm{Npr} 2^{\mathrm{cn}} / \mathrm{Npr} 2^{\mathrm{cn}}$ mice, almost all of the oocytes had no clear GV and showed apparent morphological abnormalities such as the presence of condensed chromatin (Fig. 3B) and fragmented ooplasm (Fig. 3C), indicating precocious resumption of meiosis

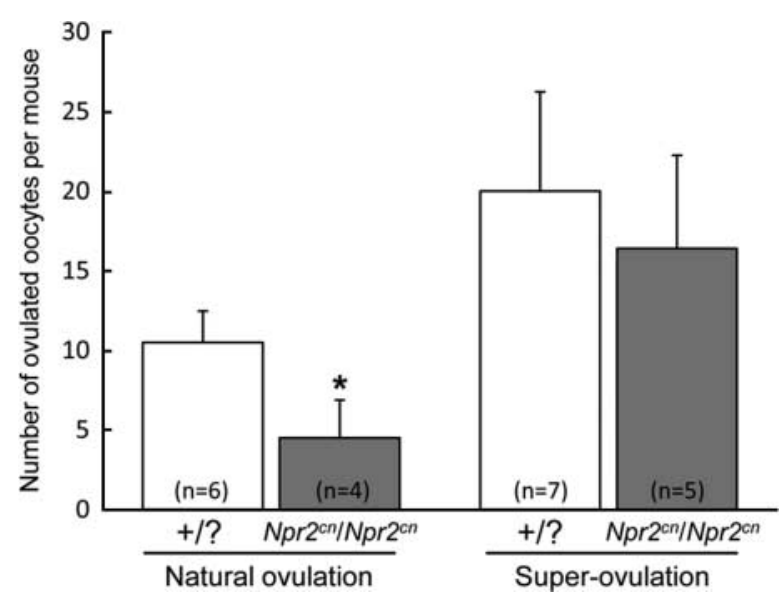

Figure 1 Comparison of the number of ovulated oocytes between $N p r 2^{c n} / N p r 2^{c n}$ and normal (+/?) mice. Number of ovulated oocytes in normal (+/?) and mutant (Npr2 $\left.2^{c n} / N p r 2^{c n}\right)$ mice during natural ovulation (left) and superovulation (right) is presented as the mean \pm S.D. Numbers in parentheses indicate the number of mice examined. An asterisk indicates a significant difference $(P<0.01)$ between normal and mutant mice. 

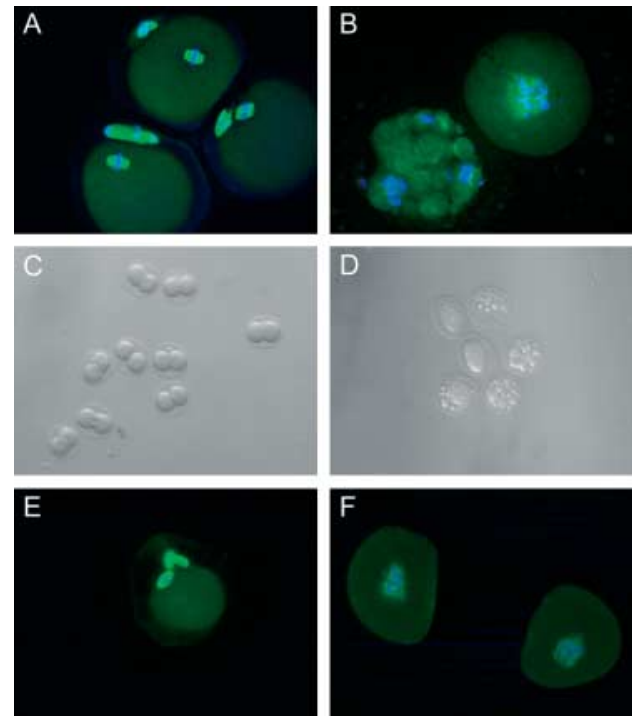

Figure 2 Morphology of ovulated oocytes in $N p r 2^{c n} / N p r 2^{c n}$, $N p c^{l b a b} / N_{p p c^{l b a b}}$ and normal (+/?) mice. Ovulated oocytes collected at MII stage from normal ( $A$ and $E$; littermates of $B$ and $F$ respectively), $N p r 2^{c n} / N p r 2^{c n}(B)$, and Nppc $c^{l b a b} / N p p c^{l b a b}(F)$ mice. Fertilized eggs at the two-cell stage collected from normal (C) and Npr $2^{c n} / N p r 2^{c n}$ (D) mice.

followed by degeneration. The proportion of oocytes with condensed chromatin or fragmented ooplasm in $N p r 2^{c n} / N p r 2^{c n}$ mice was 70.5 or $29.5 \% \quad(n=62$; the number of oocytes examined in three ovaries) respectively. In normal mice, all oocytes examined $(n=103)$ were at GV stage.

To further confirm the precocious resumption and degeneration of the oocytes in the $\mathrm{Npr} 2^{\mathrm{Cn}} / \mathrm{Npr} 2^{\mathrm{Cn}}$ mice, ovaries of 3-week-old pregnant mare serum gonadotropin (PMSG)-primed $\mathrm{Npr}^{\mathrm{cn}} / \mathrm{Npr} 2^{\mathrm{cn}}$ mice were collected $9 \mathrm{~h}$ after human chorionic gonadotropin (hCG) injection and examined to observe the progression of abnormalities in oocytes immediately before ovulation. In normal mice, oocytes of periovulatory follicles showed a metaphase spindle and underwent typical cumulus expansion $(92.5 \%, n=40$; Fig. 3D), indicating the resumption of meiosis induced by the hCG stimulation. However, in the $\mathrm{Npr} 2^{\mathrm{cn}} / \mathrm{Npr} 2^{\mathrm{cn}}$ mice, oocytes of periovulatory follicles exhibited a misaligned and dispersed configuration of chromosomes $(24.1 \%$, $n=54$; Fig. 3F) or fragmented ooplasm (27.8\%), which resembled the ovulated oocytes of the $\mathrm{Npr} 2^{\mathrm{cn}} / \mathrm{Npr} 2^{\mathrm{cn}}$ mice. These findings indicate that the precocious resumption of meiosis in the antral follicles is followed by the ovulation of fragmented or degenerated oocytes in $\mathrm{Npr}{ }^{\mathrm{cn}} / \mathrm{Npr} 2^{\mathrm{cn}}$ mice.

In addition to these oocytes abnormalities, cumulus oophorus abnormalities were found in the ovaries of the $N p r 2^{c n} / N p r 2^{c n}$ mice. In normal mice, a cumulus oophorus presented as thick layers of cumulus cells surrounding the oocytes in the antral follicles (Fig. 3A), which were expanded in periovulatory follicles (Fig. 3D). The oocytes were subsequently ovulated along with the surrounding cumulus cells as a cumulus-oocyte complex. However, despite no significant difference in the granulosa cell layers of the preantral follicles, the cumulus oophorus surrounding the oocytes in the antral follicles of 12-week-old $\mathrm{Npr} 2^{\mathrm{cn}} / \mathrm{Npr}^{\mathrm{cn}}$ mice were markedly thinner than those of normal mice (Fig. 3B and C). Furthermore, $50 \%$ of oocytes $(n=54)$ were devoid of cumulus cells in the periovulatory follicles of $N p r 2^{c n} / N p r 2^{c n}$ mice (Fig. 3E and F), which accounts for the lack of cumulus cells surrounding the ovulated oocytes of mutant mice.

\section{Morphology of ovulated oocytes and histology

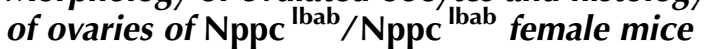

To further demonstrate that NPPC signaling through NPR2 is crucial for oogenesis and follicle development, we investigated the ovulated oocytes and ovaries of mutant mice (Nppc $\left.{ }^{I b a b} / N p p c^{l b a b}\right)$ carrying a mutation in the Nppc gene. Since the Nppc lbab/Nppc lbab homozygous mice of the original LBAB strain established by the Jackson Laboratory (Bar Harbor, ME, USA) exhibit early postnatal mortality, we were not able to obtain adult homozygous mouse of this strain. Therefore, we substituted the genetic background of the mutant strain with that of the $\mathrm{CN}$ strain (Npr2 $2^{\mathrm{cn}} / \mathrm{Npr} 2^{\mathrm{cn}}$ ) to obtain adult homozygous mice for morphological examination of oocytes and ovaries. The Nppc lbab/+ mice were backcrossed for more than eight generations to wild-type $(+/+)$ mice of the CN strain, and Nppc Ibab/Nppc Ibab
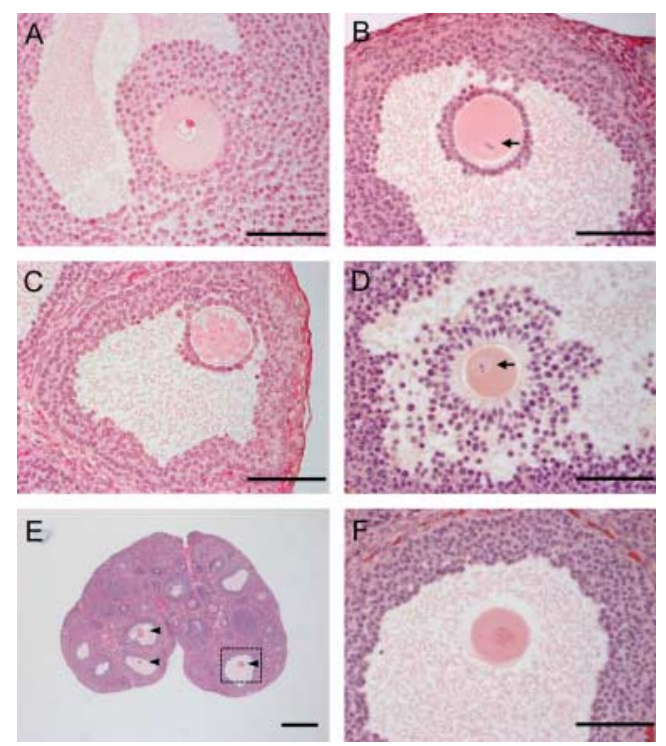

Figure 3 Histology of ovaries in $\mathrm{Npr} 2^{c n} / \mathrm{Npr} 2^{c n}$ and normal (+/?) mice. Antral follicles of normal (A) and $\mathrm{Npr}^{\mathrm{cn}} / \mathrm{Npr}^{\mathrm{cn}}$ (B and C) mice at 12 weeks of age. Follicles immediately before ovulation in PMSG-primed normal (D) and Npr2 $2^{c n} / N p r 2^{c n}$ (E and F) mice treated with hCG for $9 \mathrm{~h}$ at 3 weeks of age; (F) shows magnified views of the boxed area in (E). Arrows in (B) and (D) indicate metaphase chromosomes in oocytes. Arrow heads in (E) indicate oocytes without the cumulus oophorus. Scale bars: $100 \mu \mathrm{m}$ (A, B, C, D and F) and $500 \mu \mathrm{m}$ (E). 

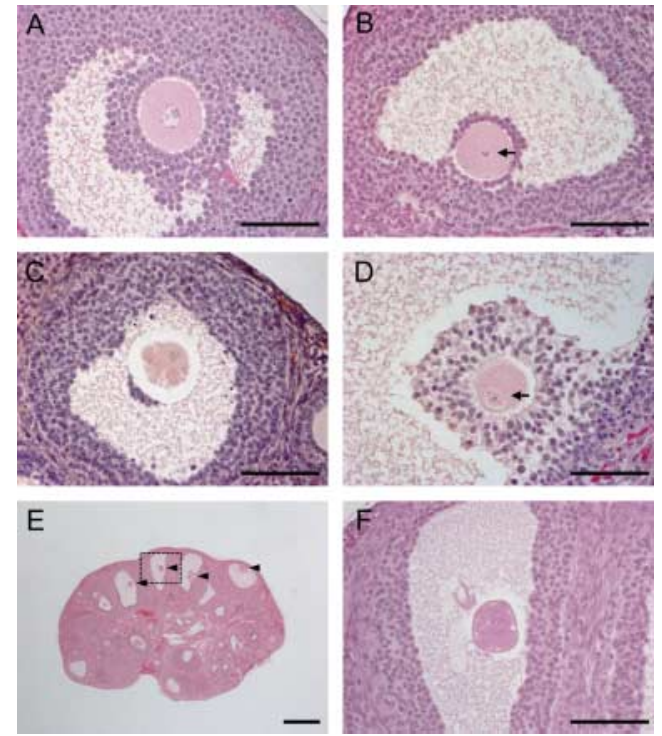

Figure 4 Histology of ovaries in $N p p c^{l b a b} / N p p c^{l b a b}$ and normal $(+/$ ? $)$

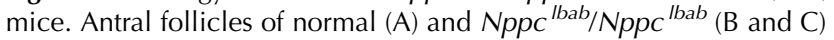
mice at 12 weeks of age. Follicles immediately before ovulation in PMSG-primed normal (D) and Nppc ${ }^{l b a b} / \mathrm{Nppc}^{\text {Ibab }}$ (E and F) mice treated with hCG for $9 \mathrm{~h}$ at 3 weeks of age; (F) shows magnified views of the boxed area in (E). Arrows in (B) and (D) indicate metaphase chromosomes in oocytes. Arrow heads in (E) indicate oocytes without the cumulus oophorus. Scale bars: $100 \mu \mathrm{m}$ (A, B, C, D and F) and $500 \mu \mathrm{m}(\mathrm{E})$.

homozygous female mice were obtained by sib-mating of these $\mathrm{Nppc} \mathrm{lbab} /+$ mice with the $\mathrm{CN}$ genetic background. No signs of pregnancy or delivery of pups in

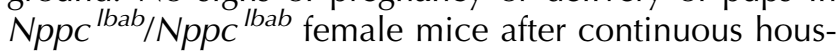
ing with male mice were confirmed. Mll-stage oocytes of heterozygous $(\mathrm{Nppc} \mathrm{lbab} /+)$ mice showed normal meiotic spindle structures and chromosome alignments (Fig. 2E), whereas oocytes ovulated from the resultant $\mathrm{Nppc}^{\text {lbab/Nppc }}{ }^{\text {lbab }}$ female mice showed condensed chromosomes (Fig. 2F), similar to those of the $N p r 2^{c n} / N p r 2^{c n}$ mice. In the ovaries of the 12-week-old mice, oocytes in the antral follicles of normal mice were maintained at the GV stage $(97.5 \%, n=81$; Fig. 4A), whereas those of Nppclbab/Nppc lbab mice resumed meiosis and developed a metaphase spindle (59.3\%, $n=59$; Fig. 4B) or fragmented ooplasm (39.0\%; Fig. 4C). In contrast to a typical cumulus expansion of normal mice that were treated with PMSG and hCG (Fig. 4D), oocytes immediately before ovulation exhibited a dispersed configuration of chromosomes $(18.4 \%$, $n=49)$ or fragmented ooplasm $(44.9 \%)$ in the ovaries of $N p p c^{l b a b} / N_{p p c} c^{l b a b}$ mice (Fig. 4E and F). Furthermore, the cumulus oophorus in the antral follicles of the $\mathrm{Nppc}{ }^{\mathrm{lbab}} / \mathrm{Nppc}^{\text {lbab }}$ mice was markedly thinner (Fig. 4B and C), and $53 \%$ of oocytes $(n=49)$ in the periovulatory follicles were devoid of cumulus cells (Fig. 4E and F), as in the $N p r 2^{c n} / N p r 2^{c n}$ mice. These results indicate that the abnormalities observed in the ovaries of
$N p r 2^{c n} / N p r 2^{c n}$ and $N p p c^{l b a b} / N p p c^{l b a b}$ mice were apparently identical, confirming that the NPPC signaling through NPR2 is crucial for oocyte meiotic arrest and cumulus oophorus formation in mice.

\section{Discussion}

In this study, we revealed that: i) $N p r 2^{c n} / N p r 2^{c n}$ female mice are infertile despite successful mating and ovulation; ii) the oocytes of mice homozygous for $N p r 2^{c n}$ or $N p p c^{\text {lbab }}$ prematurely resume meiosis in antral follicles and exhibit abnormal morphology, such as condensed chromatin or fragmented ooplasm, with no cumulus oophorus in periovulatory follicles; and iii) ovulated oocytes of mice homozygous for $\mathrm{Npr}^{\mathrm{cn}}$ or $N p p c^{\text {lbab }}$ have no developmental capacity.

Premature resumption of meiosis caused by defective NPPC/NPR2 signaling has been reported by Zhang et al.

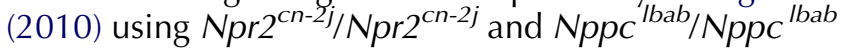
mice. However, it is notable that the premature resumption in these mutant mice was not fully proven to be caused by defective NPPC/NPR2 signaling. For example, the ovaries of the Nppc Ibab/Nppc Ibab mice were not collected under natural conditions. The authors transplanted the ovaries of $\mathrm{Nppc} c^{\mathrm{lbab}} / \mathrm{Nppc} \mathrm{c}^{\mathrm{lbab}}$ mice into the kidney capsules of normal mice to reveal the importance of NPPC produced in the ovaries for oocyte meiotic arrest. Furthermore, it has not yet been confirmed whether $N p r 2^{c n-2 j}$ has disruption of the $\mathrm{Npr} 2$ gene. A mutation of Npr2 gene in $\mathrm{Npr} 2^{c n-2 j}$ was assumed from an allelism test using mice with the $N p r 2^{c n}$ allele, but the causative mutation of $N p r 2^{c n-2 j}$ has not yet been identified. In contrast, we used adult mice homozygous for the Nppc ${ }^{l b a b}$ mutation by introducing the genetic background of the $\mathrm{CN}$ mutant mice to overcome the early death of the mutant mice; we also used $\mathrm{Npr} 2^{c n} / \mathrm{Npr} 2^{\mathrm{cn}}$ mice, in which loss-of-function mutation of the Npr2 gene has been identified (Tsuji \& Kunieda 2005). Zhang et al. (2010) reported that only 80 and $50 \%$ of oocytes in late antral follicles of $\mathrm{Npr}^{\mathrm{cn}-2 \mathrm{j}}$ $N p r 2^{c n-2 j}$ and $N p p c^{l b a b} / N p p c^{l b a b}$ mice respectively had resumed meiosis. We further revealed that following the premature resumption of meiosis, most of the oocytes showed abnormal morphology with condensed chromatin or fragmented ooplasm immediately before ovulation. These results provide concrete evidence for the etiology of female mouse infertility caused by defective NPPC/NPR2 signaling.

Our data also provide novel findings regarding the role of NPPC/NPR2 signaling in the formation of the cumulus oophorus. We found that cumulus cells surrounding

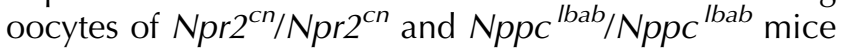
were significantly decreased in the antral follicles and were absent in periovulatory follicles. During follicular development, oocyte-secreted factors, such as growth differentiation factor-9 and bone morphogenetic protein-15, play crucial roles in controlling proliferation, 
apoptosis, and differentiation of cumulus cells (Hussein et al. 2005, Gilchrist et al. 2006, Diaz et al. 2007). Since oocytes in the antral follicles of $N p r 2^{c n} / N p r 2^{c n}$ and

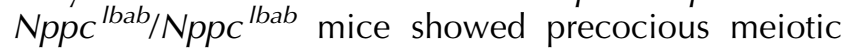
resumption, abnormalities in the cumulus cells of these mice could be caused by a deficiency in the oocytesecreted factors. However, this hypothesis is inconsistent with the observation that despite the precocious meiotic resumption of oocytes, the formation of the cumulus oophorus appears to be normal in GPR3-disrupted mice (Mehlmann et al. 2004). Another possibility is that NPPC/NPR2 signaling directly promotes cell proliferation and suppresses cell death in cumulus cells. The relevance of NPPC to cell proliferation has been demonstrated in chondrocytes (Yasoda et al. 1998, Mericq et al. 2000). cGMP, a second messenger in the NPPC/NPR2 signaling pathway, suppresses apoptosis in granulosa cells and is necessary for the development of FSH-stimulated preantral follicles (McGee et al. 1997). In addition, Npr2 mRNA is specifically expressed in the cumulus cells of antral follicles (Zhang et al. 2010). Therefore, the NPPC signal may exert its effect directly on cumulus cells through NPR2 and would thus be implicated in the proliferation and/or maintenance of cumulus cells. The effects of NPPC signal could affect the cumulus cells directly or indirectly, and further study of the follicular development of these mutant mice will provide novel findings regarding the interaction between oocytes and cumulus cells.

There are significant differences in follicular development between the NPPC/NPR2-deficient mice used in the present study and those used by Tamura et al. (2004) and Zhang et al. (2010). Tamura et al. (2004) reported that only primordial through secondary follicles were found in the ovaries of NPR2-deficient mice. On the other hand, Zhang et al. (2010) reported no major morphological differences in ovarian histology in the mutant mice. In the present study, we confirmed the presence of all follicular stages and ovulation of oocytes in both $\mathrm{Npr} 2^{\mathrm{Cn}} / \mathrm{Npr} 2^{c n}$ and Nppc ${ }^{\mathrm{lbab}} / \mathrm{Nppc} \mathrm{C}^{\mathrm{lbab}}$ mice, but found significant decreases in the number of cumulus cells in the antral follicles of both mutants. The reason for these differences in ovarian phenotypes is unknown, but a possible explanation is the different levels of residual NPPC/NPR2 activity caused by different mutations in the $N p r 2$ or Nppc genes of these mutant mice. Exons 3 to 7 of the Npr2 gene were removed in the knockout mouse used by Tamura et al. (2004), resulting in null mutation of the gene. Missense mutations have been found in the $N p r 2^{c n}$ and Nppc ${ }^{\text {lbab }}$ used in the present study, which may raise the possibility for residual NPPC/NPR2 signaling in these mice. Actually, we have revealed that NPPC derived from the Nppc Ibab allele retained a slight ability to induce cGMP production through its receptor NPR2 (Tsuji et al. 2008). As mentioned earlier, no detailed information on $N p r 2^{c n-2 j}$, including the type of mutation and the residual activity of NPR2, is currently available. Ovaries transplanted in normal mice were used to assess the ovaries of the Nppc lbab/ $N p p c^{\text {lbab }}$ mice; therefore, considerable effects of the host mouse, including circulating NPPC, could not be excluded. Considering these differences, the different levels of residual NPPC/NPR2 activity in these mutant mice may be attributed to the different phenotypes of follicular development.

Both Nppc and Npr2 are expressed in gonadotroph cells of the anterior pituitaries (McArdle et al. 1993) as well as in $\mathrm{GNRH}$-secreting cells of the hypothalamus (Olcese et al. 1994, Herman et al. 1996, Middendorff et al. 1997). In addition, the promoter activity of Nppc has shown to be stimulated by GNRH stimulation (Thompson et al. 2009). In the present study, the number of oocytes at natural ovulation was significantly decreased in the $\mathrm{Npr} 2^{\mathrm{cn}} / \mathrm{Npr} 2^{\mathrm{cn}}$ mice, but no difference was found in the number of ovulated oocytes in the superovulated $\mathrm{Npr} 2^{\mathrm{cn}} / \mathrm{Npr} 2^{\mathrm{cn}}$ mice. In addition, the $N p r 2^{c n} / N p r 2^{c n}$ mice showed no clear estrus cycles, although all stages of the estrus cycle were observed. Thus, NPPC/NPR2 signaling may contribute to the regulation of $\mathrm{FSH}$ and/or $\mathrm{LH}$ levels via GNRH-secreting cells or GNRH-responsive cells. Further investigations using NPPC/NPR2-deficient mice would help to clarify whether NPPC/NPR2 signaling is actually associated with the regulation of gonadotropin level in the hypothalamic-pituitary axis.

In conclusion, our data demonstrate that defective NPPC/NPR2 signaling in mice results in female infertility due to developmentally impaired oocytes. Since our study suggested that NPPC/NPR2 signaling is involved in oocyte meiotic resumption, ovulation rate, and the formation of the cumulus oophorus, further evidence of the roles of NPPC/NPR2 signaling in these events will be informative for therapeutic treatment of human infertility and for improving the reproductive ability of animals.

\section{Materials and Methods}

\section{Animals}

Heterozygous $\mathrm{Npr} 2^{\mathrm{cn} /+}$ and $\mathrm{Nppc} c^{\mathrm{lbab} /}+$ mice were obtained from the Jackson Laboratory. Mice homozygous for $N p r 2^{c n}$ and their normal littermates $(+/$ ?) were obtained by sib-mating heterozygotes (Npr2 ${ }^{\mathrm{Cn} /+}$ ). Mice homozygous for Nppc ${ }^{l b a b}$ and their normal littermates $(+/$ ?) were obtained by sib-mating of heterozygous $(\mathrm{Nppc} \mathrm{lbab} /+)$ mice that were backcrossed for more than eight generations to wild-type $(+/+)$ mice of the $\mathrm{CN}$ mouse strain. The genotypes of the Npr2 and Nppc genes in these mice were determined by PCR-restriction fragment length polymorphism, as described previously (Tsuji \& Kunieda 2005, Tsuji et al. 2008). All animal experiments were approved by the Animal Committee of Okayama University and were conducted in accordance with the Guidelines for Animal Experiments at Okayama University. 


\section{Collection of ovulated oocytes and embryos}

For the collection of ovulated oocytes and embryos, female mice were euthanized and their oviducts were removed from the ovaries. The oviducts were placed between two glass microscope slides and the number of ovulated oocytes was then counted by observing the ampullae of the oviducts under a stereoscopic microscope. For natural ovulation, the number of oocytes was counted in untreated female mice on the day when vaginal plugs were observed after mating with male mice. Superovulation was achieved by an i.p. injection of 5 IU PMSG followed by 5 IU hCG 48 h later. The number of oocytes from these superovulated mice was counted 14-16 h after the second injection. Data are expressed as mean \pm s.D. and statistical significance was determined using Student's $t$-test. Two-cell stage embryos were obtained from the oviducts of the female mice mated with normal male mice at 32-36 h after the hCG injection on the day following confirmation of the presence of a vaginal plug.

\section{Oocyte immunocytochemistry}

Ovulated oocytes were collected from the oviducts of the mice $14-16 \mathrm{~h}$ after the hCG injection. For immunocytochemical analysis, the oocytes were briefly incubated with $0.3 \mathrm{mg} / \mathrm{ml}$ hyaluronidase in PBS and fixed for $1 \mathrm{~h}$ in $2 \%$ formaldehyde. The oocytes were then treated with $1 \%$ Triton X-100 for $20 \mathrm{~min}$ and incubated with anti- $\alpha$-tubulin antibody (Sigma) for $1 \mathrm{~h}$ at $20{ }^{\circ} \mathrm{C}$ to visualize tubulin. After washing with PBS containing $0.1 \%$ Triton X-100, the oocytes were reacted with FITC-conjugated goat antimouse IgG antibody for $1 \mathrm{~h}$ at $20^{\circ} \mathrm{C}$. The oocytes were washed and finally mounted in Vectashield (Vector Labs, Burlingame, CA, USA) supplemented with DAPI.

\section{Histological evaluation of ovarian follicles}

Ovaries used for histological analysis were collected from female mice at 3 and 12 weeks of age. The 3-week-old mice were treated with 5 IU PMSG and their ovaries were subsequently excised $9 \mathrm{~h}$ after the hCG injection to observe oocytes immediately before ovulation. The ovaries were fixed overnight in Bouin's solution, dehydrated in ethanol, and embedded in paraffin. Specimens were sectioned at $5-\mu \mathrm{m}$ thickness and stained with hematoxylin and eosin.

\section{Declaration of interest}

The authors declare that there is no conflict of interest that could be perceived as prejudicing the impartiality of the research reported.

\section{Funding}

This study was supported by a Grant-in-Aid for Scientific Research of the Japan Society for the Promotion of Science.

\section{References}

Chusho H, Tamura N, Ogawa Y, Yasoda A, Suda M, Miyazawa T, Nakamura K, Nakao K, Kurihara T, Komatsu Y et al. 2001 Dwarfism and early death in mice lacking C-type natriuretic peptide. PNAS 98 4016-4021. (doi:10.1073/pnas.071389098)

Diaz FJ, Wigglesworth K \& Eppig JJ 2007 Oocytes are required for the preantral granulosa cell to cumulus cell transition in mice. Developmental Biology 305 300-311. (doi:10.1016/j.ydbio.2007.02.019)

Gilchrist RB, Ritter LJ, Myllymaa S, Kaivo-Oja N, Dragovic RA, Hickey TE, Ritvos O \& Mottershead DG 2006 Molecular basis of oocyte-paracrine signalling that promotes granulosa cell proliferation. Journal of Cell Science 119 3811-3821. (doi:10.1242/jcs.03105)

Herman JP, Dolgas CM, Rucker D \& Langub MC Jr 1996 Localization of natriuretic peptide-activated guanylate cyclase mRNAs in the rat brain. Journal of Comparative Neurology 369 165-187. (doi:10.1002/ (SICI)1096-9861(19960527)369:2 < 165::AID-CNE1 > 3.0.CO;2-1)

Hussein TS, Froiland DA, Amato F, Thompson JG \& Gilchrist RB 2005 Oocytes prevent cumulus cell apoptosis by maintaining a morphogenic paracrine gradient of bone morphogenetic proteins. Journal of Cell Science 118 5257-5268. (doi:10.1242/jcs.02644)

Jankowski M, Reis AM, Mukaddam-Daher S, Dam TV, Farookhi R \& Gutkowska J 1997 C-type natriuretic peptide and the guanylyl cyclase receptors in the rat ovary are modulated by the estrous cycle. Biology of Reproduction 56 59-66. (doi:10.1095/biolreprod56.1.59)

Jiao Y, Yan J, Jiao F, Yang H, Donahue LR, Li X, Roe BA, Stuart J \& Gu W 2007 A single nucleotide mutation in Nppc is associated with a long bone abnormality in Ibab mice. BMC Genetics 8 16. (doi:10.1186/14712156-8-16)

Lane PW \& Dickie M 1968 Three recessive mutations producing disproportionate dwarfing in mice. Journal of Heredity 59 300-308.

McArdle CA, Poch A \& Käppler K 1993 Cyclic guanosine monophosphate production in the pituitary: stimulation by C-type natriuretic peptide and inhibition by gonadotropin-releasing hormone in $\alpha \mathrm{T} 3-1$ cells. Endocrinology 132 2065-2072. (doi:10.1210/en.132.5.2065)

McGee E, Spears N, Minami S, Hsu SY, Chun SY, Billig H \& Hsueh AJ 1997 Preantral ovarian follicles in serum-free culture: suppression of apoptosis after activation of the cyclic guanosine $3^{\prime}, 5^{\prime}$-monophosphate pathway and stimulation of growth and differentiation by follicle-stimulating hormone. Endocrinology 138 2417-2424. (doi:10.1210/en.138.6.2417)

Mehlmann LM, Saeki Y, Tanaka S, Brennan TJ, Evsikov AV, Pendola FL, Knowles BB, Eppig JJ \& Jaffe LA 2004 The Gs-linked receptor GPR3 maintains meiotic arrest in mammalian oocytes. Science 306 1947-1950. (doi:10.1126/science.1103974)

Mericq V, Uyeda JA, Barnes KM, De Luca F \& Baron J 2000 Regulation of fetal rat bone growth by C-type natriuretic peptide and CGMP. Pediatric Research 47 189-193. (doi:10.1203/00006450-200002000-00007)

Middendorff R, Paust HJ, Davidoff MS \& Olcese J 1997 Synthesis of C-type natriuretic peptide (CNP) by immortalized LHRH cells. Journal of Neuroendocrinology 9 177-182. (doi:10.1046/j.1365-2826.1997. 00563.x)

Olcese J, Middendorff R, Münker M, Schmidt C \& McArdle CA 1994 Natriuretic peptides stimulate cyclic GMP production in an immortalized LHRH neuronal cell line. Journal of Neuroendocrinology 6 127-130. (doi:10.1111/j.1365-2826.1994.tb00562.x)

Potter LR, Abbey-Hosch S \& Dickey DM 2006 Natriuretic peptides, their receptors, and cyclic guanosine monophosphate-dependent signaling functions. Endocrine Reviews 27 47-72. (doi:10.1210/er.2005-0014)

Schulz S 2005 C-type natriuretic peptide and guanylyl cyclase B receptor. Peptides 26 1024-1034. (doi:10.1016/j.peptides.2004.08.027)

Stepan H, Leitner E, Bader M \& Walther T 2000 Organ-specific mRNA distribution of C-type natriuretic peptide in neonatal and adult mice. Regulatory Peptides 95 81-85. (doi:10.1016/S0167-0115(00)00141-5)

Suga S, Nakao K, Hosoda K, Mukoyama M, Ogawa Y, Shirakami G, Arai H, Saito Y, Kambayashi Y, Inouye K et al. 1992 Receptor selectivity of natriuretic peptide family, atrial natriuretic peptide, brain natriuretic peptide, and C-type natriuretic peptide. Endocrinology 130 229-239. (doi:10.1210/en.130.1.229)

Tamura N, Doolittle LK, Hammer RE, Shelton JM, Richardson JA \& Garbers DL 2004 Critical roles of the guanylyl cyclase B receptor in endochondral ossification and development of female reproductive organs. PNAS 101 17300-17305. (doi:10.1073/pnas.0407894101) 
Thompson IR, Chand AN, Jonas KC, Burrin JM, Steinhelper ME, WheelerJones CP, McArdle CA \& Fowkes RC 2009 Molecular characterisation and functional interrogation of a local natriuretic peptide system in rodent pituitaries, $\alpha \mathrm{T} 3-1$ and $\mathrm{L} \beta \mathrm{T} 2$ gonadotroph cells. Journal of Endocrinology 203 215-229. (doi:10.1677/JOE-09-0189)

Törnell J, Billig H \& Hillensjö T 1990 Resumption of rat oocyte meiosis is paralleled by a decrease in guanosine $3^{\prime}, 5^{\prime}$-cyclic monophosphate (cGMP) and is inhibited by microinjection of cGMP. Acta Physiologica Scandinavica 139 511-517. (doi:10.1111/j.1748-1716.1990.tb08953.x)

Tsuji T \& Kunieda T 2005 A loss-of-function mutation in natriuretic peptide receptor 2 (Npr2) gene is responsible for disproportionate dwarfism in cn/cn mouse. Journal of Biological Chemistry 280 14288-14292. (doi:10.1074/jbc.C500024200)

Tsuji T, Kondo E, Yasoda A, Inamoto M, Kiyosu C, Nakao K \& Kunieda T 2008 Hypomorphic mutation in mouse Nppc gene causes retarded bone growth due to impaired endochondral ossification. Biochemical and Biophysical Research Communications 376 186-190. (doi:10.1016/j. bbrc.2008.08.139)
Yasoda A, Ogawa Y, Suda M, Tamura N, Mori K, Sakuma Y, Chusho H, Shiota K, Tanaka K \& Nakao K 1998 Natriuretic peptide regulation of endochondral ossification. Evidence for possible roles of the C-type natriuretic peptide/guanylyl cyclase-B pathway. Journal of Biological Chemistry 273 11695-11700. (doi:10.1074/jbc.273.19. 11695)

Zhang M, Su YQ, Sugiura K, Xia G \& Eppig JJ 2010 Granulosa cell ligand NPPC and its receptor NPR2 maintain meiotic arrest in mouse oocytes. Science 330 366-369. (doi:10.1126/science.1193573)

Received 13 February 2012

First decision 19 March 2012

Revised manuscript received 15 May 2012

Accepted 12 June 2012 